\title{
ENERGY POVERTY, CLIMATE CHANGE AND ECONOMIC GROWTH
}

\section{Afaha Sylvester John ${ }^{1}$ and Ifarajimi Gilbert Deinde ${ }^{2}$}

${ }^{1}$ Department of Economics, College of Arts, Social and Management Sciences, Caleb University, Lagos State, Nigeria, and Center for Petroleum Economics, energy and Law

(CPEEL), University of Ibadan. E-mail: johnafaha@yahoo.com

${ }^{2}$ Department of Economics, College of Arts, Social and Management Sciences, Caleb

University, Lagos State, Nigeria. E-mail: bursdare@ gmail.com

Cite this article:

Afaha S.J., Ifarajimi G.D. (2021), Energy Poverty, Climate Change and Economic Growth. African Journal of Economics and Sustainable Development 4(3), 98-115. DOI: 10.52589/AJESDU3LCOYOP.

\section{Manuscript History}

Received: 13 Sept 2021

Accepted: 30 Sept 2021

Published: 19 Oct 2021

Copyright $\odot 2020$ The Author(s). This is an Open Access article distributed under the terms of Creative Commons Attribution-NonCommercialNoDerivatives 4.0 International (CC BY-NC-ND 4.0), which permits anyone to share, use, reproduce and redistribute in any medium, provided the original author and source are credited.
ABSTRACT: The study objectives were to determine the short and long-run effects of energy poverty and climate change on economic growth and to theoretically describe the driving factors of household energy poverty status using the Nigeria Demographic and Health Survey (NDHS) dataset, 2018. The Autoregressive Distributed Lagged (ARDL) model was used to estimate variables based on data from 1980 to 2018. The results indicate that energy poverty has a negative or inverse relationship with the GDP growth; energy imports contribute an average of ten percent to the value of the GDP growth. Traditional and dangerous forms of energy use are predominant in Nigerian households. This poses a threat not only to the environment but also to the health of the public. An awarenessraising campaign on using safe and environmentally friendly energy sources should be a priority in Nigeria. Likewise, energy poverty reduction interventions, probably in the form of promotion of cheap and efficient clean energy technologies in the rural sector and the northern region (most especially Northeast), should be executed to enable the households to exit the energy poverty trap. Income smoothing policy measures probably in the form of poverty reduction and safety-net programs should be directed towards the low-income earners in the country in order to ease their level of poverty, of which energy poverty is an important segment.

KEYWORDS: Energy Poverty, Climate Change, Access to Energy, Nigeria Demographic and Health Survey (NDHS) and Economic Growth. 


\section{INTRODUCTION}

Energy poverty is a situation in which people are not connected to a power grid. These people use dirty and polluting fuels and spend a great deal of their time collecting fuel to meet their needs. Such a situation is detrimental to health, income and happiness. However, climate change refers to significant changes in global temperature, precipitation, wind patterns and other climate measurements that take place over several decades or more. Climate change describes a change in the mean conditions - such as temperature and precipitation - of an area over an extended period of time. These factors include warming temperatures and changes in rainfall as well as the effects of warming the earth, such as rising sea levels. However, "poverty eradication is the biggest global challenge facing the world today and a necessary prerequisite for sustainable development, especially for developing countries...This would include actions at all levels to improve the access of the poor to reliable, affordable, economically viable, socially acceptable and environmentally sound energy services and resources, taking into account national specificities and circumstances" (Report of the World Summit on Sustainable Development, Johannesburg, 4 September, 2002).

Access to energy is a prerequisite for human development, as statistics show that one out of seven people worldwide suffers from energy poverty (TVC News, 2020). Energy is needed for individual survival, important for the provision of social services such as education and health, and a critical input in all economic sectors for household production or farming, and to industry. The wealth and developmental status of a nation and its inhabitants are closely related to the type and extent of access to energy. The more easily energy can be used and the more efficient the technologies for converting energy, the better the conditions for the development of individuals, households, communities, society and its economy. The improvement of access to energy is therefore an ongoing challenge for governments and development organisations (Energypedia, 2019).

The lack of energy in terms of quantity and quality results in a lack of development, which increases poverty and human suffering. Energy vulnerability on one hand, which is the propensity of being unable to secure materially and socially necessitated levels of domestic energy services (Bouzarovski \& Petrova, 2015) brought about by rising energy costs, are a greater burden on Nigerian communities for a variety of reasons. Income, age and type of housing, home ownership, fuel type, energy intensity, energy program access and many other factors can affect the energy costs that households face as well as their ability to pay.

The use of energy is therefore a prerequisite for virtually all economic activities, and it is crucial to be able to access sufficient amounts of energy at an acceptable cost (both from an economic and environmental perspective), which gives rise to the notion of 'energy security' (Greenleaf, Harmsen, Angelini, Green, Williams, Rix, Lefevre \& Blyth, 2009). Given the discussions above, it is critical to try to understand what these challenges mean for the future of our economies. It is equally important to understand how these challenges work together. There is a widespread recognition of how energy poverty interacts with climate change. Much less is known about how the damages caused by energy poverty, climate change and vulnerability interact and impact the Nigerian economic system or the global economy. The contribution of this research is to provide a rich literature and discussion based on arguments about energy poverty for the Nigerian economy. Therefore, to what extent will climate change in various dimensions around the world affect the energy sector? What coping mechanisms or strategies are available to address this critical threat which has been 
considered one of the greatest threats to humanity in the 21 st century? These are issues that are at the forefront of the agenda for all decision makers across the globe and a focus of this study. Therefore, the core objectives of the study are to determine the short and long-run effects of energy poverty and climate change on economic growth and to descriptively examine the driving factors of household energy poverty status using the Nigeria Demographic and Health Survey (NDHS) dataset, 2018.

\section{LITERATURE/THEORETICAL UNDERPINNING}

\section{Energy Poverty in Nigeria}

Nigeria has a rich reserve of renewable and non-renewable energy resources, including coal, crude oil and natural gas (Jack \& Tavneet, 2016). Although the proven crude oil reserves for Nigeria are more than 36,809 million barrels and 5,761 billion cu.m standard cubic meter of proven gas reserves, and Nigeria holds 379 million* tons (MMst) of proven coal reserves as of 2016, ranking 44th in the world. (OPEC, 2019; *Worldometer, 2020), most Nigerians experience acute energy poverty (Agba, 2011; Allison \& Olanshile, 2016). The country's huge energy potential, as shown in Table 1 below, if properly exploited, can meet the energy needs of over 208 million Nigerians. However, the provision of adequate, reliable, stable and uninterrupted food has remained elusive for decades (Adebayo, 2013; Enesi et al., 2015; Chidebell-Emordi, 2015).

\section{Table 1: Renewable Energy Potentials in Nigeria}

\begin{tabular}{|c|c|c|c|}
\hline Resource Type & $\begin{array}{l}\text { Capacity (Natural } \\
\text { Units) }\end{array}$ & $\begin{array}{l}\text { Production Units/Comments } \\
\text { (Natural Units) }\end{array}$ & $\begin{array}{l}\text { Utilization }^{1} \text { (Natural } \\
\text { Units) }\end{array}$ \\
\hline Large Hydropower & $14,750 \mathrm{MW}^{*}$ & 1,900 MW exploited & 167.4 Million MWh/day \\
\hline Small Hydropower & $774 \mathrm{MW}^{*}$ & 64.2 MW exploited & 2.6 million MWh/day \\
\hline Solar & $\begin{array}{l}3.5 \mathrm{kWh} / \mathrm{m}^{2} / \text { day }- \\
7.0 \mathrm{kWh} / \mathrm{m}^{2} / \text { day* }\end{array}$ & $\begin{array}{l}\text { Significant potentials for solar } \\
\text { infrastructure, both for on-grid } \\
\text { and on-grid use }\end{array}$ & $\begin{array}{l}\text { Excess of } 0.01 \text { million } \\
\mathrm{MWph} / \text { day of solar PV }\end{array}$ \\
\hline Wind & $\begin{array}{l}\text { An average of } 2-4 \mathrm{~m} / \mathrm{s} \\
@ 10 \mathrm{~m} \text { hub height }\end{array}$ & $\begin{array}{l}\text { Moderate wind potentials in the } \\
\text { country. }\end{array}$ & \\
\hline \multirow[t]{4}{*}{ Biomass } & Municipal waste & $\begin{array}{l}18.5 \text { million tonnes produced in } \\
2005 \text { and now estimated at } \\
0.5 \mathrm{~kg} / \text { capita/day }\end{array}$ & \\
\hline & Fuel wood & $\begin{array}{l}43.4 \text { million tonnes/yr of fuel } \\
\text { wood consumption }\end{array}$ & $\begin{array}{l}0.120 \text { million tonnes/day } \\
\text { or } 710.1333 \mathrm{MJ}^{*}\end{array}$ \\
\hline & Agricultural residues & 91.4 million tonnes/yr produced. & \\
\hline & Energy crops & $\begin{array}{l}28.2 \text { million hectares of arable } \\
\text { land; } 8.5 \% \text { cultivated }\end{array}$ & \\
\hline
\end{tabular}

Source: ECN (2014), Energy Implications of Vision 20: 2020 and Beyond, Report no.: ECN/EPA/2014/01. *Authors' compilation from Gwani and Abubakar, 2016.

\footnotetext{
${ }^{1}$ Muhammad, Ibrahim, Abdulhameed, Usman, Shehu, and Idoma (2014). Leye and Fagbenle (2014) and BALA and PAM (2012)
} 
Available statistics on energy poverty in Nigeria as indicated by NDHS (2018), shows that despite the fact that energy demand is growing at an annual rate of approximately $8.2 \%$, only about $59.4 \%$ of the households in Nigeria have access to electricity. Forty-six percent are without electricity. Further, an estimated $82.7 \%$ of the total urban population and just $38.9 \%$ of the rural population are connected to the national electricity grid. While $17.3 \%$ of the urban settings have no electricity, $61.1 \%$ of the rural areas have no electricity, which is very high. For a country like Nigeria with a population of over 200 million people, at least 40,000 MW (megawatts) of electricity is required to sustain the basic needs of such a population (UNDP, 2010). However, the estimated total installed capacity of the combined hydro and thermal power stations as of 2020 is $12,522 \mathrm{MW}$, with an actual available power generation capacity of about 3500-4000 MW from both the country's main distribution utility and Independent Power Plants (ITA, 2020).

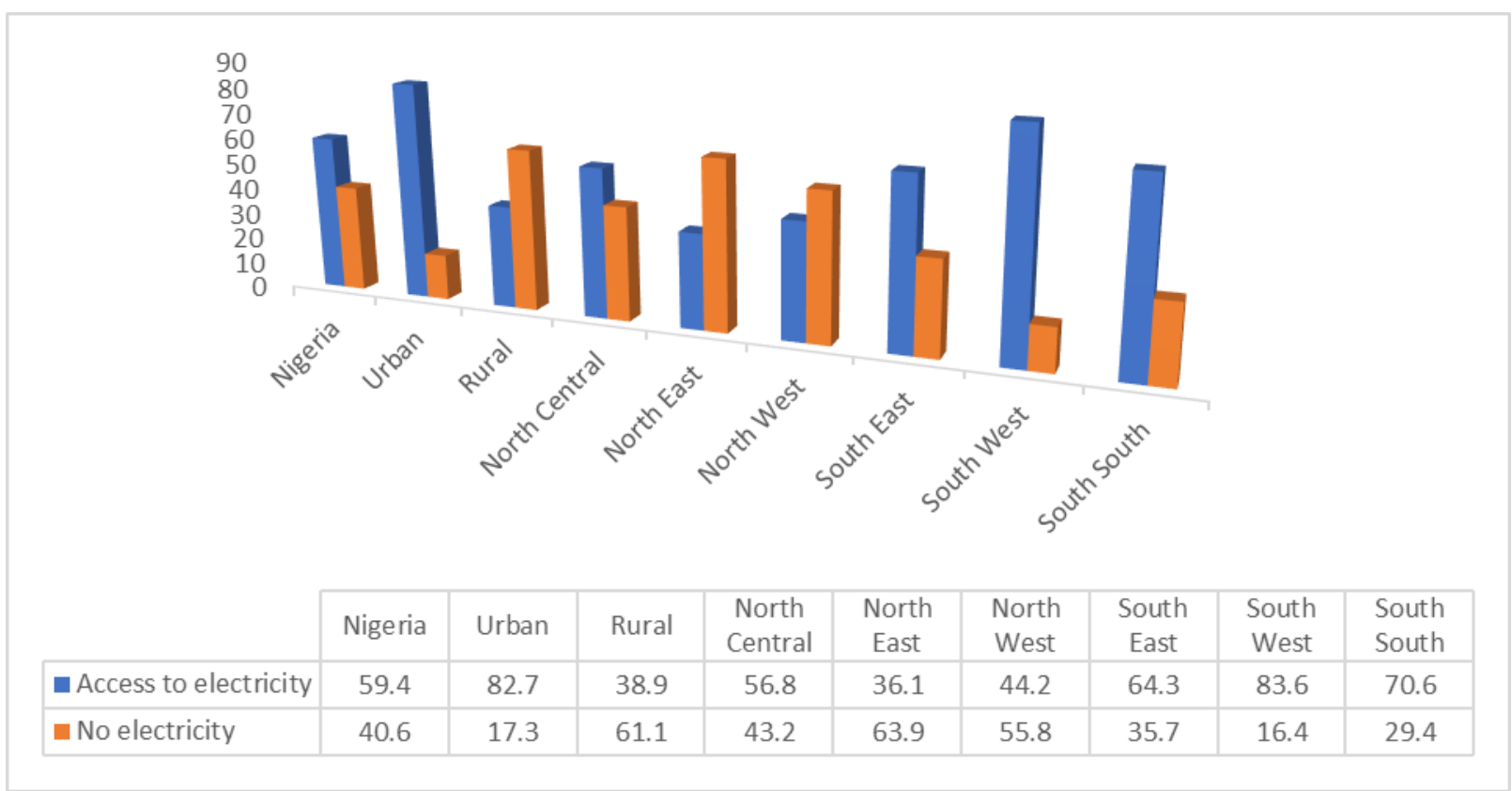

Chart 1: Household Electricity Access by Sector and Region. Source: NDHS, 2018.

Another dimension of widespread Nigerian energy poverty is domestic lighting. In most households in Nigeria, due to large-scale electricity scarcity, kerosene lamps, charged torches and candles are used for lighting after sunset. For households that can afford a personal generator set, most rely on the smaller generators popularly known as "I pass my neighbor" while the relatively well-to-do's rely on bigger generator sets and lister generators of various sizes. The cost of buying gasoline and diesel to operate these generators is an enormous financial burden on most households. Supporting this assertion, Chidebell-Emordi (2015) observes that private self-generating with portable generators accounts for electricity supply for about $72 \%$ residents in urban Southwestern Nigeria alone, thus making Nigeria the world's largest concentration of small-scale generators. 
The third dimension of energy poverty in Nigeria is the lack of access to clean, reliable and affordable kitchen energy for most Nigerians. Available statistics show that over $60 \%$ of Nigerians (about 117.8 million people) both in rural and urban areas still rely on wood and biomass as major sources of cooking energy (Allison \& Olanshile, 2016; Sa'ad \& Bugaje, 2016; Ogunwale, 2015; Lavelle, 2013). Furthermore, data from chart 2 below computed from the Nigeria Bureau of Statistics' Annual Statistical Abstract (2011), cited in Sa'ad and Bugaje (2016) on the regional distribution of household dependence on firewood use in Nigeria, shows that Northern Nigeria has a higher dependence rate on fuel wood consumption with the North East recording a $93.7 \%$ dependence, North West $91.8 \%$, and North Central $74.0 \%$, while South East has a $66.0 \%$ dependence, South-South $58.7 \%$ and South West, a 37.2\% dependence rate.

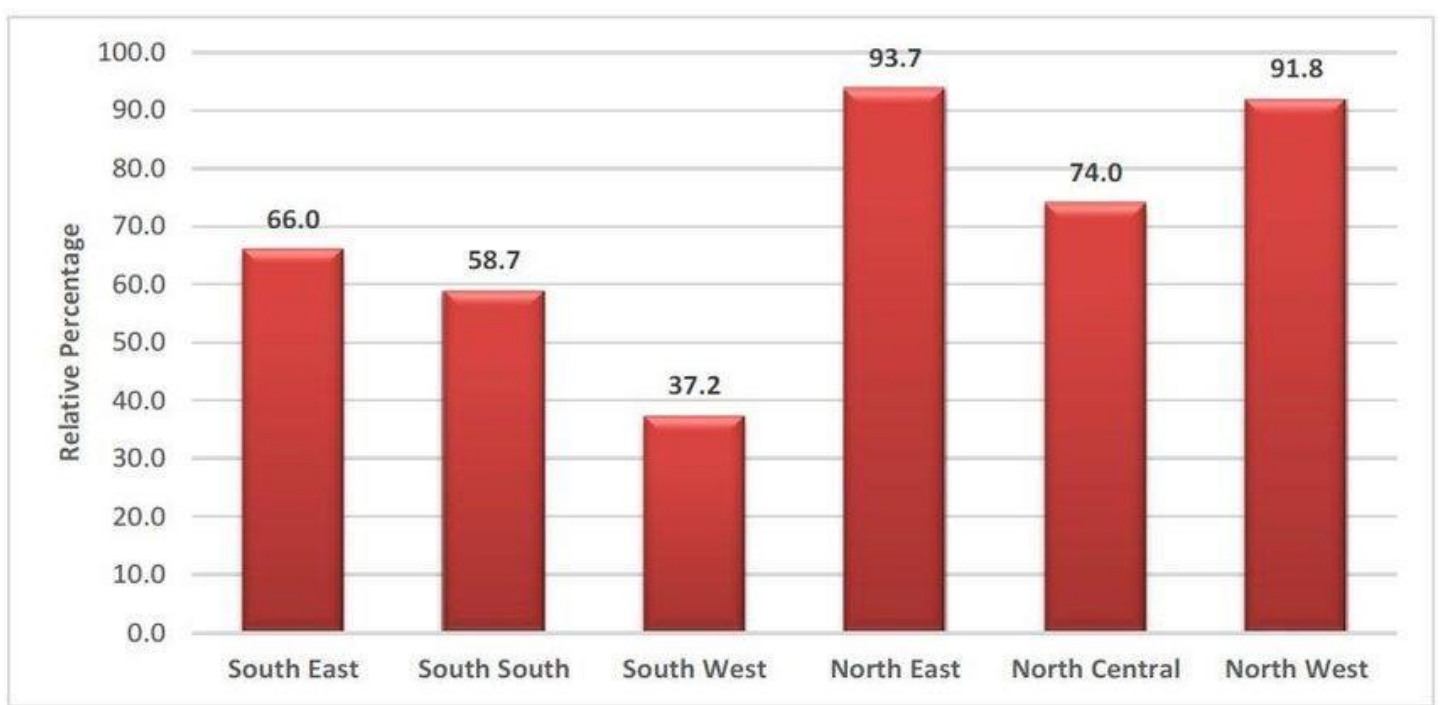

Chart 2: Households Dependent on Firewood for Cooking by Regions in Nigeria (\%). Source: Annual Abstract of Statistics, 2011, National Bureau of Statistics cited in Sa'ad \& Bugaje, 2016

The inter-relationship between energy and poverty which has been established (Chakravarty \& Tavoni, 2013; Kanagawa \& Nakata, 2007; Pachauri, S., et al., 2004) proved to be the main problem of energy security, affecting mainly women and children in developing countries (Spagnoletti, 2013). While high poverty prevalence is known to affect the energy consumption pattern of households, their access to clean and reliable energy is believed to aid in alleviating poverty as increased access to energy allows for more growth economically (Ahlborg, H. \& Hammar, L., 2014; Ohunakin, Adaramola, Muyiwa, Oyewola, Olarenwaju, Fagbenle \& Richard, 2014). 


\section{Stylised Fact on Energy Poverty and Climate Change in Nigeria}

Climate change is an undeniable environmental threat of the 21st century that the world is currently living and searching for measures to adapt to and mitigate its impact. The United Nations Framework Convention on Climate Change (UNFCCC) defines climate change as "a change which is attributed directly or indirectly to human activity that alters the composition of the global atmosphere over comparable time periods" (IPCC, 2007). Climate change is already changing the way of life on earth. Around the globe, seasons change, temperatures rise, and sea levels rise. Climate change affects the whole world; the poorest people who contribute the least to change are those who suffer the most. Scientific research shows that the net climate created by the change will be largely fueled by atmospheric greenhouse gases. Climate change will adversely affect the Nigerian economy with various observable impacts ranging from a significant reduction in agricultural productivity to increased rates of disease, morbidity and mortality. The energy sector has also not been ignored because climate change has had an impact on hydropower, which is a source of electricity for the country. Many other sectors such as transport, tourism and manufacturing have all been affected, generally affecting the overall Nigerian economy and its GDP. As per studies conducted by the Department for International development (DFID), it was estimated that climate change will cost Nigeria between 6 percent and 30 percent of its GDP by 2050, worth between $\$ 100$ billion and $\$ 460$ billion.

The ability of the Kainji Dam hydropower project to perform as designed has been greatly hampered by the drought which has ravaged most of the West African countries bordering on the Sahara for the past three years. The impact of this drought on power plants has led to a drastic reduction in the planned power supply to the Kainji Dam. To locate the nexus of modern energy access and climate resilience systematically, the vulnerability framework of coupled human-environment systems by Turner, Matson, McCarthy, Corell, Christensen, Eckley, Hovelsrud-Broda, Kasperson, Kasperson, and Luers (2003) was used as a guiding framework. Their framework shows that the vulnerability of a certain community or a household to changes in the environment is not only a matter of exposure to the stress but also of existing biophysical and socio-economic factors. Through this framework illustrated in Chart 3, access to energy services can be considered as a type of human capital and/or enhancer of human capital (Sensitivity: Human Conditions) that increase the overall resilience of vulnerable households to the changing environment. Improvement or eradication of about a billion heavy polluting stoves would also have significant carbon savings that would bring short-term climate benefits to a more or less extent, decreasing household exposure to climatic changes. In addition, the amount of deforestation avoided by provisioning modern energy sources can be considered as both mitigation of carbon emissions from land use changes and conservation of natural capital (Sensitivity: Environmental Conditions). The success of climate change adaptation and mitigation actions is thus inevitably interlinked with people's access to proper energy services, which would build human and social capacity to adapt to future climate surprises.

\section{Stylised Fact on Energy Poverty and Economic Growth in Nigeria}

In measuring economic growth as Adams (2004) pointed out, choosing the measures can have a significant impact on analyses of the relationship between growth and poverty reduction. Though most studies use growth in GDP per capita (e.g., Balakrishnan, Steinberg \& Syed, 2013; Wieser, 2011; Bourguignon, 2003; Kraemer \& Gugerty, 1997), others use 
growth in average incomes from household surveys (e.g., De Janvry \& Sadoulet, 2010; Kraay, 2006; Adams, 2004). Some studies also use growth in sectoral value added to GDP to compare the impacts of growth in different sectors (e.g., De Janvry \& Sadoulet, 2010; Loayza $\&$ Raddatz, 2010). Adams (2004) finds that economic growth, measured by changes in mean income or consumption from household survey data, has a stronger statistical association with poverty reduction than growth measured by changes in GDP per capita.

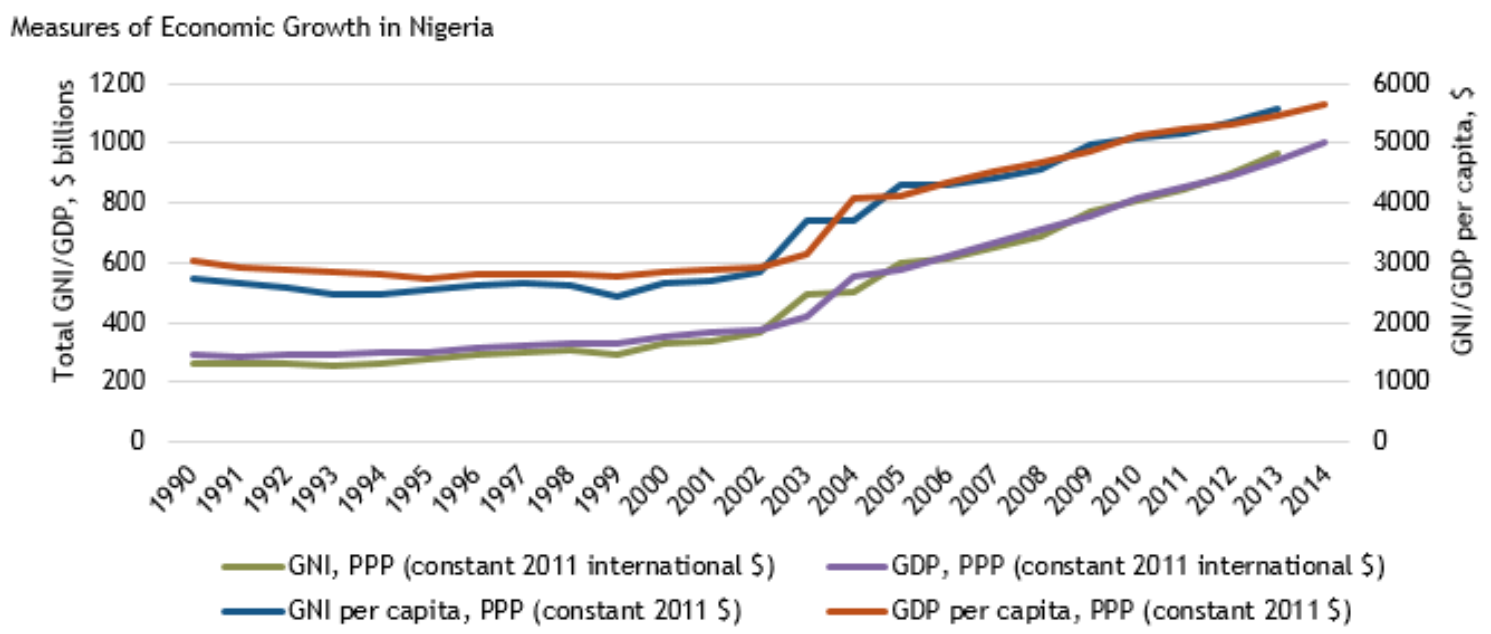

Chart 3: Measures of Economic Growth in Nigeria. Source: World Bank, 2015b

We find that World Bank measures of Gross National Income (GNI) and Gross Domestic Product (GDP) in Nigeria are relatively consistent, but differ over time (Chart 3), indicating that there are differences between income earned domestically by non-citizens and income earned by Nigerians abroad. While GDP per capita was higher between 1990 and 2001, the relative magnitude of GNI and GDP measures alternated between 2002 and 2006 and appears almost identical between 2006 and 2013. The trends for GNI and per capita GDP measures reflect those for GNI and total GDP. All of these figures are adjusted for Purchasing Power Parity (PPP), a calculation which uses the cost of a common basket of goods and services to eliminate the differences in price levels between countries, supporting comparability (OECD, 2015b).

\section{Measuring Poverty}

As with choosing a measure of economic growth, different approaches to measuring poverty may also affect estimates and alter interpretations. Poverty measures try to represent the wellbeing of people living below an acceptable minimum level of consumption or income (World Bank, 2015a). The poverty headcount, for example, considers the number of people that fall below a poverty line; thus, in order to make cross-country poverty comparisons using poverty headcounts, local currencies are converted to a common currency (usually USD) using purchasing power parity (PPP) rates (World Bank, 2015a). The current international poverty 
level is set at $\$ 1.90$ per day at PPP rates (ibid.). The poverty headcount ratio meanwhile measures the incidence of poverty by dividing the number of people under the poverty line by the total population. The most recent data on Nigeria's poverty headcount indicate there were 82.99 million people living below $\$ 1.90$ per day in 2009 , for a poverty headcount ratio of $53.47 \%$ (World Bank, 2015b). Studies on economic growth and poverty most commonly use the poverty headcount ratio as the measure of poverty (e.g., Wieser, 2011; Loayza \& Raddatz, 2010; Adams, 2004; Kraemer \& Gugerty, 1997).

Despite Nigeria's GDP and GNI data being measured each year and available up to 2020, the poverty ratio and the poverty gap are less consistently estimated. The World Bank and the Nigerian National Bureau of Statistics (NBS) use Nigeria's National Living Standards Survey (NLSS) data to estimate the poverty rate. This household survey (or a similar earlier version) is collected approximately every five years and the most recent data available is from the 2018-19 survey wave. In addition to these poverty data, UNDP estimates for the MPI in Nigeria are available for 2008, 2011, 2013, 2019 and 2020. Figure 4 illustrates the poverty estimates from these three sources.

Nigeria Poverty Estimates

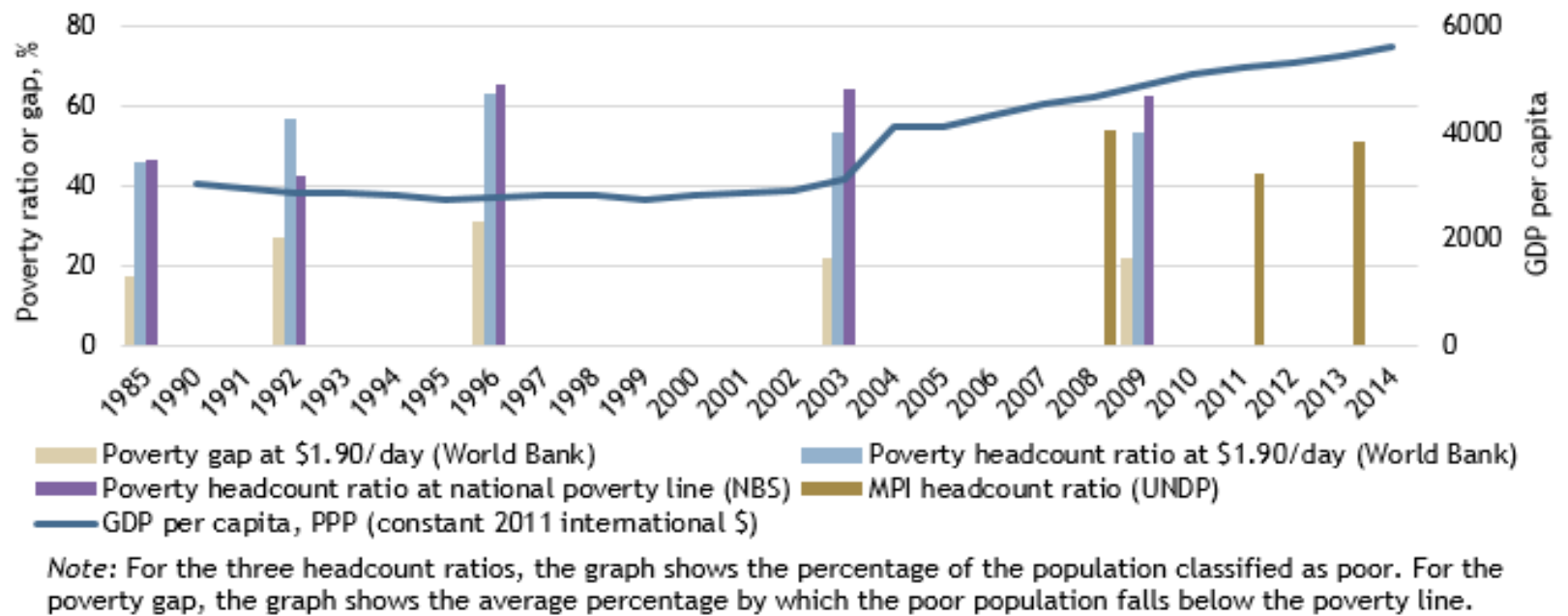

\section{Chart 4: Nigerian Poverty Estimates.}

\section{METHODOLOGY}

The estimation technique adopted is an autoregressive distributed lag model (ARDL), boundtesting, estimation approach and the Granger causality test. The rationale for this technique is that it enables a level I (0) and the first difference I (1) integration order. The short and longrun dynamics among the variables considered can be determined based on the ARDL and its impact on economic growth. Secondly, to achieve the second objective, the dataset obtained from the National Demographic Health Survey collected by the National Bureau of Statistics 
(NBS) is used. The data set includes 2766 rural households and 1283 urban households. Descriptive statistics have been used to profile socioeconomic characteristics of households.

\section{Empirical Specifications of the Model Used}

GDPgrowth $=\mathrm{f}$ (energy climate change)

GDPgrowth $=\mathrm{F}$ [energy poverty, measured using energy poverty (access to electricity: energy_poverty_access), access to clean fuel and technology (ACFT), carbon monoxide $\left(\mathrm{CO}_{2}\right)$ intensity, energy intensity (energy_intensity) level of primary energy, energy imports (energy_imports), and climate change (measured by annual mean rainfall, (AMRain)]

Using equation (2), the general representation of the functional form ARDL is set out as follows:

$$
\begin{aligned}
& \Delta G D P \text { growth }=\alpha_{0}+\sum_{i=1}^{n} \phi_{i} \Delta G D P \text { growt } h_{t-1}+\sum_{i=0}^{p} \theta_{i} \Delta A C F T_{t-1}+\sum_{i=0}^{q} \Omega_{i} \Delta C O 2 \text { int ensity } t_{t-1}+ \\
& \sum_{i=0}^{k} \gamma_{i} \Delta \text { energy_imports } t_{t-1}+\sum_{i=0}^{v} \vartheta_{i} \Delta \text { energy_int ensity } y_{t-1}+\sum_{i=0}^{v} \varpi_{i} \Delta e n e r g y_{-} \text {poverty_access }_{t-1} \\
& +\sum_{i=0}^{v} \tau_{i} \Delta A M \operatorname{Rain}_{t-1}+\varepsilon_{t}
\end{aligned}
$$

If all the variables are as defined earlier, $\Delta$ is the difference operator and is the error term. To trace the existence of cointegration, statistical $\mathrm{F}$ is calculated from the ARDL regression of the equation (3). The null hypothesis of no cointegration is tested by restricting the lagged level variables equal to zero against the alternate hypothesis. The bounds tests provide two asymptotic critical value bounds. The lower bound assumes the variables are I (0) while the upper bound assumes I (1) variables. The non-cointegration null hypothesis is rejected if the calculated F statistic is above the upper limit of the critical value; otherwise, the null hypothesis is not rejected. Based on equation (3), the following ARDL based error correction model required for the short run result is specified as follows:

$$
\begin{aligned}
& \Delta G D P \text { growth }=\alpha_{0}+\sum_{i=1}^{n} \phi_{i} \Delta G D P \text { growth } t_{t-1}+\sum_{i=0}^{p} \theta_{i} \Delta A C F T_{t-1}+\sum_{i=0}^{q} \Omega_{i} \Delta C O 2 \text { int } \text { ensity }_{t-1}+ \\
& \sum_{i=0}^{k} \gamma_{i} \Delta e n e r g y \_ \text {imports }_{t-1}+\sum_{i=0}^{v} \vartheta_{i} \Delta \text { energy_int ensity }{ }_{t-1}+\sum_{i=0}^{v} \varpi_{i} \Delta \text { energy_poverty_access } s_{t-1} \\
& +\sum_{i=0}^{v} \tau_{i} \Delta \operatorname{AMRain}_{t-1}+\varepsilon_{t}
\end{aligned}
$$




\section{RESULTS/FINDINGS}

\section{Unit Root Test}

The unit root test is performed using the Augmented Dickey-Fuller (ADF) test and the standard Phillips-Perron unit root test for time series analysis. The results from these two tests are shown in Table 3 below:

Table 3: Unit Root Test Results

\begin{tabular}{|c|c|c|c|c|}
\hline \multirow[t]{2}{*}{ Variable } & \multicolumn{4}{|c|}{ Unit Root Test } \\
\hline & & $\begin{array}{l}\text { ADF and t- } \\
\text { statistics in } \\
\text { brackets }\end{array}$ & Probability & $\begin{array}{l}\text { Order of } \\
\text { Cointegration }\end{array}$ \\
\hline GDP growth & Level & -3.422398 & 0.0166 & $\mathrm{I}(0)$ \\
\hline \multirow{2}{*}{$\begin{array}{l}\text { Access to clean fuel } \\
\text { and technology } \\
\text { (ACFT) }\end{array}$} & Level & -2.663883 & & \\
\hline & 1st Difference & $\begin{array}{l}-6.217323 \\
(-2.943427) * *\end{array}$ & 0.0000 & $\mathrm{I}(1)$ \\
\hline \multirow[t]{2}{*}{ CO2_intensity } & Level & -0.999176 & & \\
\hline & 1st Difference & $\begin{array}{l}-7.953945 \\
(-2.610263)^{*}\end{array}$ & 0.0000 & $\mathrm{I}(1)$ \\
\hline \multirow[t]{2}{*}{ energy_imports } & Level & -1.417990 & & \\
\hline & 1st Difference & $\begin{array}{l}-6.729518 \\
(-3.621023) * * *\end{array}$ & 0.0000 & $\mathrm{I}(1)$ \\
\hline \multirow[t]{2}{*}{ energy_intensity } & Level $* * *$ & -1.339861 & & \\
\hline & 1st Difference & $\begin{array}{l}-5.655419 \\
(-2.943427) * *\end{array}$ & 0.0000 & $\mathrm{I}(1)$ \\
\hline energy_poverty_access & Level ** & $\begin{array}{l}-2.663883 \\
(-2.960411)^{* *}\end{array}$ & 0.0917 & $\mathrm{I}(0)$ \\
\hline $\begin{array}{l}\text { Annual mean rainfall } \\
\text { (AMrain) }\end{array}$ & Level & $\begin{array}{l}-2.945842 \\
(-2.941145)^{* *}\end{array}$ & 0.0627 & $\mathrm{I}(0)$ \\
\hline
\end{tabular}

Source: Author's Computation from the Regression Results, 2021. Note: **denotes 5\% level of significance, $*$ denotes $10 \%$ and $* * * 1 \%$ level of significance. The optimal lag structure is determined by Schwarz Info Criterion. Source: Author's Estimation from Eviews 9, 2021.

The results indicate that none of the series is integrated by I (2) or more. Test for stationarity shows that all variables are integrated of order one I (1), that is the first difference, and integrated of order zero I (0), which is a strong justification for the method used. 
African Journal of Economics and Sustainable Development

ISSN: $2689-5080$

Volume 4, Issue 3, 2021 (pp. 98-115)

\section{Empirical Results of the Estimated Model}

Bounds Tests and Cointegrating Results

ARDL Bounds Test

Null Hypothesis: No long-run relationships exist

Test Statistic Value $\quad$ K

F-statistic $4.348442 \quad 6$

Critical Value Bounds

$\begin{array}{ll}\text { Significance } & \text { I0 Bound } \\ \text { I1 Bound }\end{array}$

$\begin{array}{lll}10 \% & 2.12 & 3.23 \\ 5 \% & 2.45 & 3.61 \\ 2.5 \% & 2.75 & 3.99 \\ 1 \% & 3.15 & 4.43\end{array}$

Source: Author's Computation from the Regression Results, 2021

From the bound test results above, the ARDL cointegration results are shown. The basic rule is that statistics F must be higher than upper limit I1 and lower limit I0. It follows therefore that the values of the upper and lower bounds coefficient for 5\% significance level are 3.61 and 2.45 respectively, and the F-statistics is 4.34 which is higher than the lower bounds coefficients and the upper bound coefficients. We therefore reject the null hypothesis and accept the alternative which implies that a long-term relationship exists among the variables used.

\section{Cointegrating and Long Run Form of Variables Used}

ARDL Cointegrating And Long Run Form

Dependent Variable: GDP_GROWTH

Selected Model: ARDL $(1,1,1,1,1,1,1)$

Sample: 19802018

Included observations: 38 
African Journal of Economics and Sustainable Development ISSN: 2689-5080

Cointegrating Form

\begin{tabular}{crrrr}
\hline Variable & Coefficient & Std. Error & t-Statistic & Prob. \\
& & & & \\
\hline & & & & \\
D(ENERGY_POVERTY_ACCESS) & -0.686546 & 0.301301 & -2.278607 & 0.0319 \\
D(ENERGY_INTENSITY) & 2.676711 & 0.715526 & 3.740898 & 0.0010 \\
D(ENERGY_IMPORT) & -0.003604 & 0.067871 & -0.053093 & 0.9581 \\
D(CO2_INTENSITY) & 6.715568 & 7.012425 & 0.957667 & 0.3478 \\
D(AVERAGE_MEAN_RAINFALL_ & 0.031621 & 0.025625 & 1.233986 & 0.2292 \\
D(P) & & & & \\
CointEq(-1) & 2.363549 & 1.398193 & 1.690432 & 0.1039 \\
& -0.556757 & 0.169034 & -3.293759 & 0.0031 \\
\hline
\end{tabular}

Cointeq $=$ GDP_GROWTH $-(-0.1158 *$ ENERGY_POVERTY_ACCESS + $0.6774 *$ ENERGY_INTENSITY + 0.1863*ENERGY_IMPORT -13.5634 *CO2_INTENSITY + 0.1462*AVERAGE_MEAN_RAINFALL_P -1.3009 $* \mathrm{ACFT}+10.8426)$

Long Run Coefficients

\begin{tabular}{crrrr}
\hline Variable & Coefficient & Std. Error & t-Statistic & Prob. \\
& & & & \\
\hline ENERGY_POVERTY_ACCESS & -0.115813 & 0.271391 & -0.426738 & 0.6734 \\
ENERGY_INTENSITY & 0.677444 & 0.985613 & 0.687333 & 0.4985 \\
ENERGY_IMPORT & 0.186333 & 0.172893 & 1.077731 & 0.2919 \\
CO2_INTENSITY & - & 14.798648 & -0.916531 & 0.3685 \\
& 13.563418 & & & \\
AVERAGE_MEAN_RAINFALL_P & 0.146181 & 0.089377 & 1.635565 & 0.1150 \\
ACFT & -1.300879 & 2.791943 & -0.465940 & 0.6455 \\
C & 10.842584 & 15.364589 & 0.705687 & 0.4872
\end{tabular}

\section{DISCUSSIONS}

The error-correction coefficient is negative (-0.556757), as required, and is very significant. Importantly, the long-run coefficients of the cointegrating equation are reported with their standard errors, t-statistics, and p-values. So, what are we concluding about all this? First, as might be expected, there is a long-term equilibrium relationship between access to power (as measured by energy_poverty_access) and energy intensity. Second, there is a relatively fast adjustment of GDP growth when access to electricity (as measured by energy_poverty_access) and energy intensity, among other variables changes. 


\section{Empirical Results of the Estimated Model}

Table 4 shows the findings of the Autoregressive Distributed Lag (ADRL) based on the empirical analysis of the relationship between energy poverty, climate change and economic growth in Nigeria. The dependent variable used is Real Gross Domestic Product growth (GDP_growth), while the independent variables are access to clean fuel and technology (ACFT), CO2 intensity (CO2_intensity), energy imports (energy_imports), energy intensity (energy_intensity), energy poverty access to electricity (energy_poverty_access), and climate change variable represented as (average mean rainfall, (AM Rain).

\section{Table 4: The ARDL Regression Results}

Dependent Variable: GDP_GROWTH

Method: ARDL

Included observations: 38 after adjustments

Dependent lags: 1 (Fixed)

Dynamic regressors (1 lag, fixed): ENERGY_POVERTY_ACCESS

ENERGY_INTENSITY ENERGY_IMPORT CO2_INTENSITY

AVERAGE_MEAN_RAINFALL_P ACFT

Fixed regressors: $\mathrm{C}$

\begin{tabular}{crrrr}
\hline Variable & Coefficient & Std. Error & t-Statistic & Prob.* $^{*}$ \\
& & & & \\
\hline GDP_GROWTH(-1) & 0.443243 & 0.169034 & 2.622218 & 0.0149 \\
ENERGY_POVERTY_ACCESS & -0.686546 & 0.301301 & -2.278607 & 0.0319 \\
ENERGY_POVERTY_ACCESS(-1) & 0.622067 & 0.233691 & 2.661923 & 0.0136 \\
ENERGY_INTENSITY & 2.676711 & 0.715526 & 3.740898 & 0.0010 \\
ENERGY_INTENSITY(-1) & -2.299540 & 0.678698 & -3.388164 & 0.0024 \\
ENERGY_IMPORT & -0.003604 & 0.067871 & -0.053093 & 0.9581 \\
ENERGY_IMPORT(-1) & 0.107345 & 0.052464 & 2.046073 & 0.0519 \\
CO2_INTENSITY & 6.715568 & 7.012425 & 0.957667 & 0.3478 \\
CO2_INTENSITY(-1) & -14.26709 & 8.414104 & -1.695616 & 0.1029 \\
AVERAGE_MEAN_RAINFALL_P & 0.031621 & 0.025625 & 1.233986 & 0.2292 \\
AVERAGE_MEAN_RAINFALL_P(-1) & 0.049767 & 0.027998 & 1.777505 & 0.0882 \\
ACFT & 2.363549 & 1.398193 & 1.690432 & 0.1039 \\
ACFT(-1) & -3.087822 & 1.741808 & -1.772769 & 0.0890 \\
C & 6.036680 & 8.089448 & 0.746241 & 0.4628 \\
R-squared & & & & \\
Adjusted R-squared & 0.662134 & Mean dependent var & 3.174706 \\
S.E. of regression & 0.479123 & S.D. dependent var & 5.538560 \\
Sum squared resid & 3.997278 & Akaike info criterion & 5.886414 \\
Log likelihood & 383.4775 & Schwarz criterion & 6.489735 \\
F-statistic & -97.84187 & Hannan-Quinn criter. & 6.101071 \\
Prob(F-statistic) & 3.618006 & Durbin-Watson stat & 2.403615 \\
& 0.003128 & & & \\
& & & &
\end{tabular}

*Note: p-values and any subsequent tests do not account for model selection.

Source: Author's Computation from the Regression Results, 2021 


\section{Discussion of Findings}

The results of the ARDL regression show the results of the coefficients in the short run. Based on the results presented above, the current and lagged variables of one period of energy poverty (i.e., energy_poverty_access) are significant. By implication, it simply means that energy poverty has a negative or inverse relationship with the GDP growth, contributing $68 \%$ decline to the GDP growth in the nation in the short run. In the case of energy_import, it contributes $10 \%$ of the GDP over the first period lag in the short run. The energy_intensity contributes $2 \%$ on the average to the gross domestic product growth. With respect to the effects of climate change on GDP growth, the $\mathrm{CO} 2$ intensity is not statistically significant but shows a coefficient of $6 \%$ and is negative $(-14 \%)$, meaning it does not really have an effect on the economy for now in the short run. Mean precipitation is statistically significant, contributing approximately $0.05 \%$ (coefficient of 0.049767 ) to GDP growth. Given these outcomes, this means that climate change variables have a mixed impact on economic growth.

Results also show that access to clean fuel and technology (ACFT) has a negative relationship with economic growth. It contributed $-3.08 \%$ of GDP growth. These trends need to be reversed to enable people to contribute more to GDP growth with access to clean fuels and technologies. We must get better infrastructure in place.

\section{Objective two (2): A Descriptive Examination of the Driving Factors of Household Energy Poverty Status Using the National Demographic Health Survey (NDHS) Dataset, 2018.}

Table 5 (chart of this distribution is presented in chart 5 and 6) profiles households' energy poverty across sectors, zones and in the country as a whole. There is a distinct disparity in the energy poverty of households living in the north and south of the country. The Multidimensional Energy Poverty Index (MEPI) shows that the three regions of the NorthNorth-West, North-East and North-Central-have lower energy requirements than the three regions of the South. The three regions in the South combined a MEPI average of 0.267 against 0.487 in the North. Again, when these are compared to the national average, all the Northern geopolitical zones (North-Central, 0.41; Northwest, 0.48; and Northeast, 0.57) are worse off in terms of energy poverty than the national average of 0.38 . On the other hand, all three southern zones have MEPI below the national average (Southwest 0.27; Southeast, 0.28; and South-South, 0.25). The implication of the regional performance is that the energy, wellbeing of households in the south is better than the national value, with the South-South zone having the least EPI (least energy deprived of households).

Table 5: Distribution of Energy Poverty among Households in Nigeria.

\begin{tabular}{|l|l|l|l|l|l|l|}
\hline & & \multicolumn{2}{|l|}{ Energy Poor } & \multicolumn{2}{l|}{ Energy Non-Poor } & \\
\hline & & Frequency & Percentage & Frequency & Percentage & Scores \\
\hline National & & 2293 & 56.63 & 1756 & 43.37 & 0.38 \\
\hline \multirow{3}{*}{ Sector } & Urban & 346 & 26.97 & 937 & 73.03 & 0.17 \\
\cline { 2 - 7 } & Rural & 1947 & 70.39 & 819 & 29.61 & 0.47 \\
\hline \multirow{2}{*}{ Zone } & North Central & 423 & 60.69 & 274 & 39.31 & 0.41 \\
\cline { 2 - 7 } & North East & 477 & 82.96 & 98 & 17.04 & 0.57 \\
\hline
\end{tabular}


African Journal of Economics and Sustainable Development ISSN: 2689-5080

\begin{tabular}{|l|l|l|l|l|l|l|}
\hline & North West & 575 & 71.08 & 234 & 28.92 & 0.48 \\
\cline { 2 - 7 } South East & 285 & 43.71 & 367 & 56.29 & 0.28 \\
\cline { 2 - 7 } South-South & 248 & 38.99 & 388 & 61.01 & 0.25 \\
\cline { 2 - 7 } & South West & 285 & 41.91 & 395 & 58.09 & 0.27 \\
\hline
\end{tabular}

Source: Nigeria Demographic and Health Survey, 2018

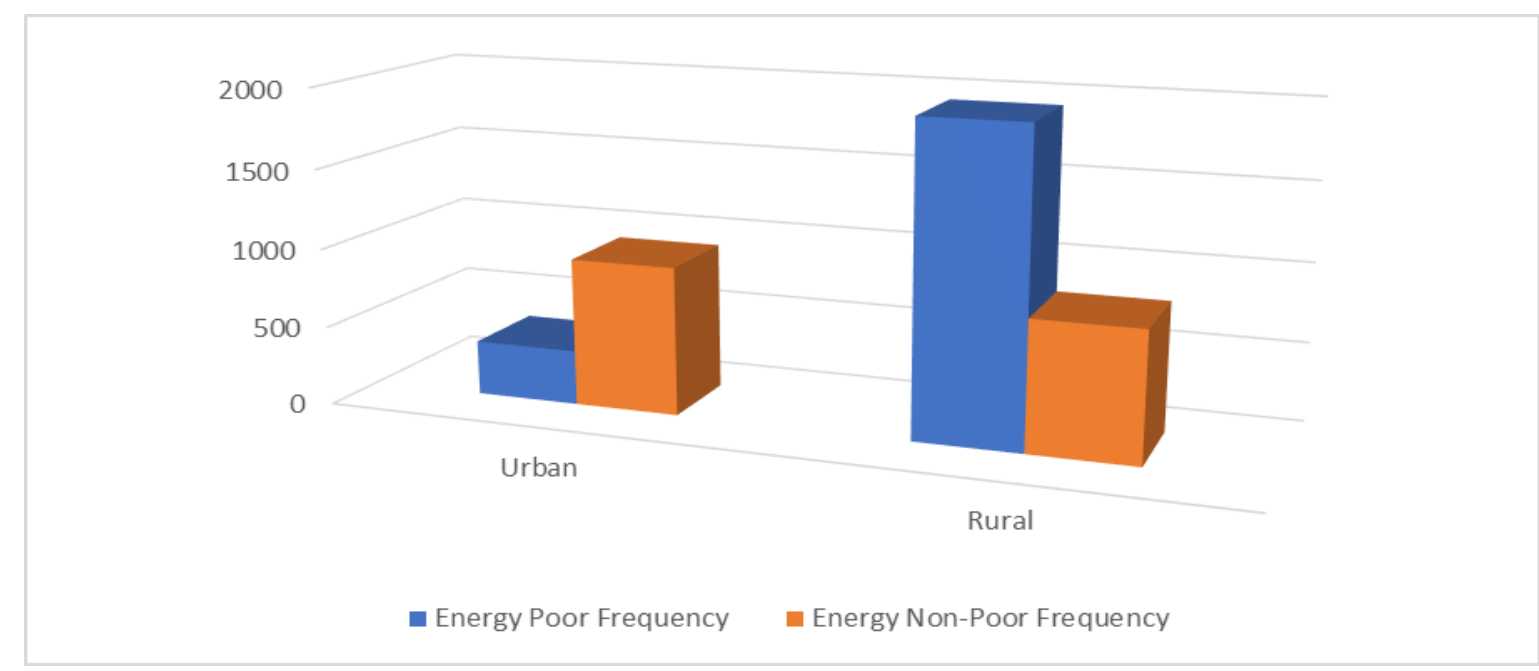

Chart 5: Percentage of Households That Are Energy Poor Across Sectors in Nigeria. Source: Nigeria Demographic and Health Survey, 2018

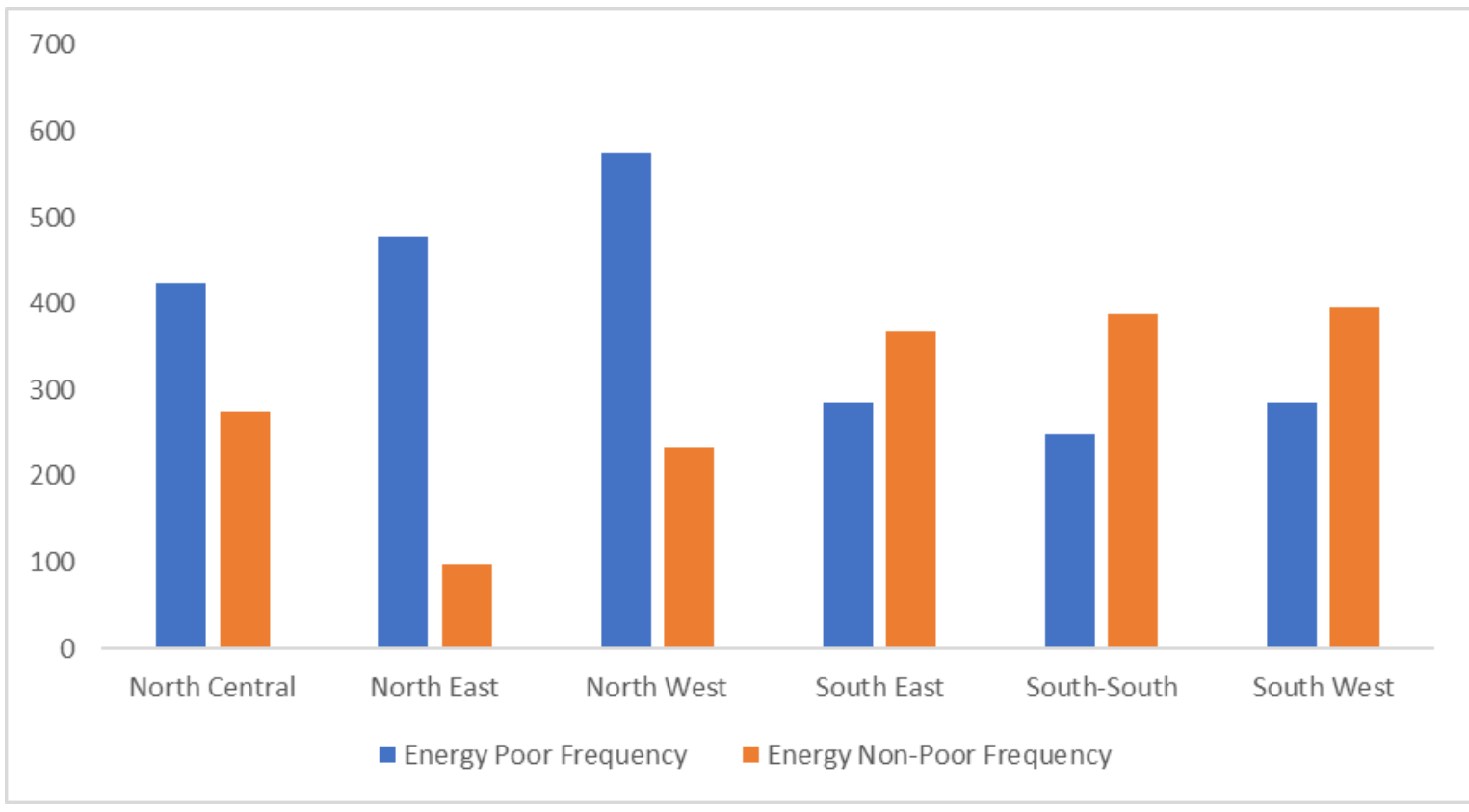

Chart 6: Percentage of Households that are Energy Poor across Zones in Nigeria. Source: Nigeria Demographic and Health Survey, 2018 
Therefore, the results of the study show that nearly six out of 10 Nigerians are energy-poor. This indicates a relatively high level of the energy problem in the country. The South-South zone has the highest percentage of energy non-poor households $(61.01 \%)$ followed by the Southwest zone $(58.09 \%)$ and the Southeast zone $(56.29 \%)$. However, the Northeast $(17.04 \%)$ has the smallest percentage of residents who are not energy poor. Thus, energy poverty appears to be more severe in northern Nigeria than in southern Nigeria. The table further shows that energy poverty is far higher in the rural $(70.39 \%)$ than in the urban sector (26.97\%), with the rural sector having 0.3 EPI value higher than that of the urban. The result of this study conforms to that of Ozughalu and Ogwumike (2015), who reported that $75.5 \%$ of Nigerians are energy poor and that the North and rural sector are the worst hit.

\section{CONCLUSION}

The results of the study clearly show that energy poverty plays an important role in Nigeria. The sustainable use of clean and safe sources of energy is indeed a global challenge. Traditional and unsafe forms of energy use are predominant in Nigerian households. Not only does this pose a threat to the environment, it also poses a risk to the health of the population. Furthermore, energy poverty has a negative or inverse relationship to GDP growth; energy imports contribute to the average of ten per cent of the value of GDP growth. Factors related to climate change have a mixed effect on economic growth. This is revolutionary in that climatic and meteorological variations are more or less a major determinant of economic growth. The relative damages from not reducing greenhouse gas emissions across all temperature ranges are especially severe, and the results suggest that changes in environmental policies are likely to be more impactful. Reducing $\mathrm{CO} 2$ will benefit big cities because better weather conditions for human habitation are desirable; high agricultural production and other sectors will help drive economic growth. A campaign to raise awareness of the use of safe and environmentally responsible energy sources should be a priority in Nigeria. Likewise, energy poverty reduction interventions, probably in the form of promotion of cheap and efficient clean energy technologies in the rural sector and the northern region (most especially Northeast), should be executed to enable the households to exit the energy poverty trap.

Also, the income smoothing policy measure probably in the form of poverty reduction and safety-net programmes should be directed towards the low-income earners in the country, in order to ease their level of poverty, of which energy poverty is an important segment. The study stresses the need to examine more complex input data in order to address and explain energy poverty so that appropriate policy measures can be taken. As the proliferation of energy poverty is not necessarily a sign of population density or population growth, other factors must be considered, such as substance and condition of buildings, and geographical situations, amongst others.

\section{Future Research}

To learn from this study, knowledge can be broadened by looking at this study in terms of energy poverty, climate change and economic growth from the perspective of Africa. This will allow the study to focus on the African continent and draw valuable insights. 


\section{REFERENCES}

Adams, R. H. (2004). Economic growth, inequality and poverty: estimating the growth elasticity of poverty. World Development, 32(12), 1989-2014.

Adebayo, C. (2014). How is 100\% Renewable Energy Possible for Nigeria? Global Energy Network Institute (GENI), March 2014.

Ahlborg, H. and L. Hammar (2014), Drivers and barriers to rural electrification in Tanzania extension, off-grid, and renewable energy technologies. Renewable Energy. 61:117124.

Allison, T.F., \& Olanshile, A. (2016). Deforestation and Climate Change in the Niger Delta: Examining the role of energy poverty. Wilberforce Journal of Social Sciences, 1(1), 1-14

Balakrishnan, R., Steinberg, C. \& Syed, M. (2013). The elusive quest for inclusive growth: Growth, poverty, and inequality in Asia. (IMF Working Paper). Washington, DC: International Monetary Fund. Retrieved from https://www.imf.org/external/pubs/ft/wp/2013/wp13152.pdf

Bourguignon, F. (2003). The growth elasticity of poverty reduction: Explaining eterogeneity across countries and time periods. In T. Eichner \& S.J. Turnovsky (Eds.), Inequality and growth: Theory and policy implications (CESifo seminar series). Cambridge, Mass.: MIT Press Buckley, R.M. and S. Tsenkova. (2001), Urban Housing and Land Market Reforms in Transition Countries: Neither Marx Nor Market (Washington, D.C, World Bank).

Bouzarovski, S. and Petrova, S. (2015). A global perspective on domestic energy deprivation: Overcoming the energy poverty - fuel poverty binary. Energy Research \& Social Science, 10, 31-40.

Chakravarty, S. and M. Tavoni, Energy poverty alleviation and climate change mitigation: Is there a trade off? Energy Economics, 2013. 40, S67-S73.

Chidebell-Emordi, C. (2015). The African electricity deficit: Computing the minimum energy poverty line using field research in urban Nigeria. Energy Research and Social Science, 5, 9-19.

De Janvry, A., \& Sadoulet, E. (2010). Agricultural growth and poverty reduction: Additional evidence. The World Bank Research Observer, 25(1), 1-20. doi: 10.1093/wbro/lkp015

Energypedia (2019). https://energypedia.info/wiki/Access_to_Modern_Energy\#Overview Energypedia (2019). https://energypedia.info/wiki/Energy_Poverty

Enesi, D. O., Ezechukwu, O. A., \& Ugwu, M. A. (2015). Nigeria"es Energy Poverty: Increasing Rural Electricity Access through Viable and Sustainable Distributed Generation Projects. International Journal of Emerging Technology and Advanced Engineering, 5 (10), 323-326.

Greenleaf, J, Harmsen, R, Angelini, T, Green, D, Williams, A, Rix, O, Lefevre, N, and Blyth, W. (2009). Analysis of Impacts of Climate Change Policies on Energy Security. Being the final report of Ecofys, ERAS and RedPoint Energy by order of: European Commission DG Environment.

IPCC (2007) Climate Change 2007: Synthesis Report, Cambridge University Press, Cambridge Jack W, and Tavneet S., (2016). The long-run poverty and gender impacts of mobile money. Science 09 Dec 2016, Vol. 354, Issue 6317, pp. 1288-1292. DOI: 10.1126/science.aah5309

Kanagawa, M. and T. Nakata, Analysis of the energy access improvement and its socioeconomic impacts in rural areas of developing countries. Ecological Economics, 2007. 62, 319-329. 
Lavelle, M. (2013, May 30). Five Surprising Facts About Energy Poverty. National Geographic. Available at: http://news.nationalgeographic.com/news/ energy/2013/05/130529---surprising---facts---about---energy---poverty/

Loayza, N. V., \& Raddatz, C. (2010). The composition of growth matters for poverty alleviation. Journal of Development Economics, 93, 137-151.

Nigeria Demographic and Health Survey (NDHS) dataset, 2018. Nigeria National Bureau of Statistics (NBS). https://africaopendata.org/dataset/nigeria-demographic-and-healthsurvey-2018.

OECD (2015b). Purchasing power parities: Frequently asked questions (FAQs). Retrieved from http://www.oecd.org/std/prices-ppp/purchasingpowerparitiesfrequentlyaskedquestionsfaqs.htm

Ogunwale, A.O. (2015). Deforestation and Greening the Nigerian Environment. International Conference on African Development Issues (CU-ICADI) 2015.

Ohunakin, Olayinka \& Adaramola, Muyiwa \& Oyewola, Olarenwaju \& Fagbenle, Richard. (2014). Solar energy applications and development in Nigeria: Drivers and barriers. Renewable and Sustainable Energy Reviews. 32. 294-301. 10.1016/j.rser.2014.01.014.

OPEC, (2019). Organization of petroleum exporting countries, 2019.

Ozughalu, U.M.; Ogwumike, F.O (2015). Food poverty profile for Nigeria. J. Dev. Areas 2015, 49, 183-201.

Pachauri, S., et al., On Measuring Energy Poverty in Indian Households. World Development, 2004. 32: p. 2083-2104.

Sa'ad, S., and I. M. Bugaje. (2016). Biomass Consumption in Nigeria: Trends and Policy Issues. Journal of Agriculture and Sustainability 9 (2): 127-157. Accessed December 20, 2019. https://infinitypress.info/index.php/jas/article/viewFile/1316/593.

Spagnoletti, B. (2013). a Let there be light: A multi-actor approach to alleviating energy poverty in Asia. Energy Policy, 2013. 63: p. 738-746.

Stefan Bouzarovski and Saska Petrova (2015). A global perspective on domestic energy deprivation: Overcoming the energy poverty-fuel poverty binary. Journal of Energy Research \& Social Science 10 (2015) 31-40

Turner, B. L., II, Matson, P. A., McCarthy, J. J., Corell, R. W., Christensen, L., Eckley, N., Hovelsrud-Broda, G. K., Kasperson, J. X., Kasperson, R. E., Luers, A., et al. (2003) Proc. Natl. Acad. Sci. USA 100, 8080-8085.

United Nations Development Programme (2010). Energy for Sustainable Future. New York. United Nations Development Program.

Wieser, C. (2011). Determinants of the growth elasticity of poverty reduction: Why the impact on poverty reduction is large in some developing countries and small in others. Paper presented at the 15th Annual Conference on Global Economic Analysis, Geneva, Switzerland. Retrieved from www.gtap.agecon.purdue.edu

World Bank (1993). The World Bank's Role in the Electric Power Sector: A World Bank Policy Paper (Washington, D.C, World Bank).

World Bank (2015a). FAQs: Global poverty line update. Washington, DC: The World Bank. Retrieved from http://www.worldbank.org/en/topic/poverty/brief/global-poverty-linefaq

World Bank (2015b). World Bank data: Nigeria. Washington, DC: The World Bank. Retrieved from http://data.worldbank.org/country/nigeria

World Bank (2015c). Measuring inequality. Washington, DC: The World Bank. Retrieved from http://go.worldbank.org/3SLYUTVY00 